\title{
Students' perceptions of the academic learning environment in seven medical sciences courses based on DREEM
}

This article was published in the following Dove Press journal:

Advances in Medical Education and Practice

23 March 2015

Number of times this article has been viewed

\author{
Hamid Bakhshialiabad' \\ Mohammadhosien Bakhshi \\ Gholamhossein \\ Hassanshahi $^{3}$ \\ 'Department of Medical Education, \\ Rafsanjan University of Medical \\ Sciences, Rafsanjan, Iran; ${ }^{2}$ Shahid \\ Sodoghy University of Medical \\ Sciences, Yazd, Iran; ${ }^{3}$ Department \\ of Microbiology, Hematology and \\ Immunology, Faculty of Medicine, \\ Rafsanjan University of Medical \\ Sciences, Rafsanjan, Iran
}

Objective: Learning environment has a significant role in determining students' academic achievement and learning. The aim of this study is to investigate the viewpoints of undergraduate medical sciences students on the learning environment using the Dundee Ready Education Environment Measure (DREEM) at Rafsanjan University of Medical Sciences (RUMS).

Methods: The descriptive cross-sectional study was performed on 493 medical sciences students in the following majors: nursing, midwifery, radiology, operating room nursing, laboratory sciences, medical emergency, and anesthesia. The DREEM questionnaire was used as a standard tool. Data were analyzed using SPSS (v17) software. Student's $t$-tests and analysis of variance (ANOVA) statistical tests were used.

Results: The mean of the achieved scores in the five domains was 113.5 out of 200 (56.74\%), which was considered to be more positive than negative. The total mean scores for perception of learning, teaching, and atmosphere were 27.4/48 (57.24\%), 24.60/44 (55.91\%), and 26.8/48 (55.89\%), respectively. Academic and social self-perceptions were 20.5/32 (64.11\%) and 15.7/28 (56.36\%), respectively. The total DREEM scores varied significantly between courses $(P<0.01)$. The total scores of the students of operating room nursing, anesthesia, and laboratory sciences, first year students, and females were significantly higher than the other students $(P<0.01)$.

Conclusion: The results have suggested that the students of medical sciences courses at RUMS generally hold positive perceptions toward their course environment. The differences between courses and their study pathway should be further investigated by analysis of specific items. Our results showed that it is essential for faculty members and course managers to make more efforts toward observing principles of instructional designs, to create an appropriate educational environment, and to reduce deficits in order to provide a better learning environment with more facilities and supportive systems for the students.

Keywords: students, learning environment, educational programs, Rafsanjan University of Medical Science

\section{Introduction}

Learning environment has been defined as everything that is happening in the classroom or department, faculty, or university. ${ }^{1}$ Learning environment refers to the diverse physical locations, contexts, and cultures in which students learn. The term encompasses the culture of a school or class and its presiding ethos and characteristics, including how students interact with and treat one another, as well as the ways in which teachers may organize an educational setting to facilitate learning. Since the qualities and characteristics of a learning environment are determined by a wide variety of factors, school policies, governance structures, and other features may also be considered elements of a "learning environment". 2
Correspondence: Hamid Bakhshialiabad Department of Medical Education, Rafsanjan University of Medical Sciences, Imam Ali St, Central Office of Rafsanjan University of Medical Sciences, Educational Development Center (EDC), Rafsanjan, Iran

Tel +98343428 0039

Fax +98343428 0097

Email hamid234I@gmail.com 
Studies have shown that the educational environment affects students' achievement, happiness, motivation, and success..$^{3-8}$ The quality of the educational environment is indicative of the effectiveness of an educational program. The educational environment subscales correlate positively with academic success and satisfaction toward educational programs. $^{3-5}$ The foundation for improving the health and safety of patients starts with the competency of health care providers. Their education is fundamental to these health initiatives. $^{9}$

In 1998, the World Federation for Medical Education highlighted the learning environment as one of the targets for the evaluation of medical education programs. ${ }^{9-11}$ It is widely agreed among medical educators that the academic and clinical environment are important influences on the attitudes, knowledge, skills, progression, and behaviors of medical students. ${ }^{10,12}$

The students' perceptions of the educational setting can be a basis for implementing modifications and thus optimizing the educational environment. Meaningful learning correlates positively with the students' perceptions of the educational environment, which impacts on students' learning experiences and outcomes. It influences how, why, and what students learn. ${ }^{13}$ It is possible to assess and modify the educational environment. ${ }^{14}$

The students' perceptions of their educational environment have been studied at all the levels of educational systems. ${ }^{3,4,10,13,14}$ Because of the recent imperatives towards enhanced quality assessment monitoring and the commitment of the health profession education towards student-centered teaching and learning, we are witnessing a revival of interest in this field. ${ }^{4,6,9}$ The accomplishment and contentment of students depends upon their learning environment. Learning environment research seeks to assess the students' perceptions of their environment and can guide medical teachers to introspect, devise, and incorporate the best teaching strategy for the improvement of the educational environment. Educational environment research assesses what is happening in a medical school; ${ }^{14}$ it provides complete and detailed information on the education process, the results of which can be used to enhance students' satisfaction and achievement. ${ }^{3-7,15}$

Student satisfaction is an important indicator of the quality of learning experiences and is related to several outcome variables. In this regard researchers have been guided in their thinking by the learning theories that stress the need and value of the learning environments that provide active and engaging activities for students. ${ }^{15,16}$ The evaluation of the educational environment is critical to the delivery of a high-quality, student-centered curriculum. ${ }^{12}$ In order to conduct such evaluation across many sites, specialties, and student groups, the use of a wide-ranging, valid, and reliable instrument is essential. Educators and researchers have tried to define and measure the medical education environment in the past, ${ }^{14,17-19}$ and the most widely used contemporary development is almost certainly the Dundee Ready Education Environment Measure (DREEM), ${ }^{14}$ which was developed by an international Delphi panel in Dundee, Scotland, UK. It is a worldwide, validated instrument that provides medical teachers with diagnostic help to measure the overall state of affairs in the learning environment of their college ${ }^{14}$ and has been translated into various languages, including Swedish, Greek, Spanish, Chinese, Arabic, Malay, Portuguese, Norwegian, Persian, and Thai. ${ }^{5,13,20-22}$ The DREEM has been used in studies in Europe, Asia, Africa, North America, South America, and the Middle East, and has since been applied in many countries. ${ }^{20-29}$ DREEM has been found to be reliable in a variety of settings, by which educational managers can identify limitations and formulate changes in curricula. ${ }^{4,21,30}$

It has been used to identify weaknesses in curricula ${ }^{23,31-34}$ and has been applied to assess the impact of new curricular interventions. ${ }^{32,34,35}$ Its focus on student experience has led to its usage in identifying the gap between student expectations and experience ${ }^{36}$ and student actual and idealized experience. ${ }^{7}$ Furthermore, the differences between student experiences at different sites within medical schools ${ }^{14,37}$ and between students' perceptions at different stages of their medical education ${ }^{36,38}$ have also been examined by the DREEM. One important use of the DREEM has been as a utility for international comparisons between medical schools..$^{38,39}$

This instrument has been applied to a number of undergraduate courses for health professionals and a variety of health care settings worldwide, ${ }^{1,40}$ such as medical, dental, nursing, paramedical sciences, and chiropractic learning environments. ${ }^{4,7,13-30}$

Many universities use a basic approach to verify students' needs by considering students as the main stakeholders in their own education..$^{28}$ The environment of an educational system determines the quality and quantity of its products, including the graduated bodies. Over the years, researchers have worked to identify the factors that contribute to the overall environment and the extent of these factors. In order to be able to measure the climate, they compare it with the product and then improve the product. ${ }^{27}$ The relationship between university students' perceptions of their academic environment, their approaches to study, and academic outcomes has been investigated at both university and faculty levels. The results 
have confirmed students' perceptions as influencing both "hard" (academic achievement) and "soft" (satisfaction and development of key skills) learning outcomes, both directly and mediated through their approaches to study. Perceptions of heavy workload and inappropriate assessment have influenced students towards surface, and perceptions of good teaching towards deep approaches to study. Students' perceptions of their current learning environment were a stronger predictor of learning outcomes at university than prior achievement at school. ${ }^{6,41}$ An essential part of identifying what has worked and where improvements could be made in the future is obtaining the "feedback" from students about the design and implementation of the learning and its environment. ${ }^{2,4,6}$

Despite the numerous medical sciences schools (both state and private), there are few studies in developing countries that focus on medical sciences education.

The current study was undertaken at Rafsanjan University of Medical Sciences (RUMS; undergraduate faculty), which is a public medical sciences university established in 1986 and located in the southeast of Iran, and which offers undergraduate, graduate, and postgraduate programs (with 14 majors). The purpose of this study was to measure the viewpoints of undergraduate students studying midwifery, radiology, operation room nursing, laboratory sciences, nursing, medical emergency, and anesthesia toward their learning environment at RUMS. The obtained data were compared based on age, sex, year of enrollment, marital status, and native and non-native status, using the DREEM. This model was used to evaluate problem areas that should be remediated and to foster learning environments that may enhance academic achievement at RUMS.

\section{Materials and methods}

\section{Participants, questionnaire, procedure, and data analysis}

A cross-sectional survey design was conducted using a standardized self-report scale. The ethics approval of the study was granted by the RUMS Standing Committee on Ethics in Research Involving Humans in 2009-2010. The samples were composed of 527 students. The subjects were chosen by a stratified random sampling method based on the students' courses from the total student population $(\mathrm{N}=610)$. The participants consisted of undergraduate health science students (nursing [ $\mathrm{n}=216]$, midwifery [ $\mathrm{n}=68]$, radiology $[\mathrm{n}=55]$, operating room nursing [ $n=50]$, laboratory sciences $[n=48]$, medical emergency $[n=38]$, and anesthesia $[n=55])$. The participants received an explanatory statement detailing the study and were informed that all data collected would remain anonymous. Participants' consent of the statistical program in this study was inferred by their completion of the questionnaire. The Persian version of DREEM with accepted validity and reliability was used to collect data ${ }^{13,41}$ on the student's demographic characteristics, including sex, marital status, native/non-native status, and age. The questionnaires were distributed to students in each health science program toward the end of a lecture; a non-teaching member of staff facilitated the process and collected the completed surveys.

The DREEM questionnaire consists of 50 items; each is scored $0-4$ on a five-point Likert scale ( $4=$ strongly agree, $3=$ agree, $2=$ unsure, $1=$ disagree, and $0=$ strongly disagree). However, nine out of 50 items (numbers 4, 8, 9, 17, 25, 35, 39, 48 , and 50) were negative statements and had to be scored in a reverse manner. The base for the overall DREEM score is 200 . The DREEM can also be used to identify more specific strengths and weaknesses within the education environment. For this purpose, it is necessary to evaluate the response to individual items being reviewed. Items with a mean score of $\geq 3.5$ are true positive points. Any item with a mean score of $\leq 2$ should be examined more closely, since this indicates a problem area. Items with a mean of 2-3 are aspects that could be enhanced. The questionnaire generates an overall "score" for the course. The statements may also be subdivided to provide an indication of student perceptions of five major domains of educational environment (Table 1), including perception of learning (12 items/maximum [max] score 48 ), perception of the teacher (eleven items/max score 44),

Table I The approximate guide to interpreting DREEM Scores

\begin{tabular}{|c|c|c|}
\hline Total score & $\begin{array}{l}\text { Students' } \\
\text { perception } \\
\text { of teachers }\end{array}$ & $\begin{array}{l}\text { Students' academic } \\
\text { self-perceptions }\end{array}$ \\
\hline-50 Very poor & 0-II Abysmal & $\begin{array}{l}0-8 \text { Feelings of total } \\
\text { failure }\end{array}$ \\
\hline $\begin{array}{l}51-100 \text { Plenty } \\
\text { of problems }\end{array}$ & $\begin{array}{l}12-22 \text { In need of } \\
\text { some retraining }\end{array}$ & $\begin{array}{l}\text { 9-16 Many negative } \\
\text { aspects }\end{array}$ \\
\hline $\begin{array}{l}101-150 \text { More positive } \\
\text { than negative }\end{array}$ & $\begin{array}{l}\text { 23-33 Moving in } \\
\text { the right direction }\end{array}$ & $\begin{array}{l}\text { 17-24 Feeling more } \\
\text { on the positive side }\end{array}$ \\
\hline $\begin{array}{l}|5|-200 \\
\text { Excellent }\end{array}$ & $\begin{array}{l}\text { 34-44 Model } \\
\text { teachers }\end{array}$ & 25-32 Confident \\
\hline $\begin{array}{l}\text { Students' perception } \\
\text { of learning }\end{array}$ & $\begin{array}{l}\text { Students' social } \\
\text { self-perceptions }\end{array}$ & $\begin{array}{l}\text { Students' perception } \\
\text { of atmosphere }\end{array}$ \\
\hline $0-12$ Very poor & 0-7 Miserable & $\begin{array}{l}\text { 0-12 A terrible } \\
\text { environment }\end{array}$ \\
\hline $\begin{array}{l}\text { I3-24 Teaching is } \\
\text { viewed negatively }\end{array}$ & $\begin{array}{l}\text { 8-14 Not a nice } \\
\text { place }\end{array}$ & $\begin{array}{l}\text { 13-24 There are many } \\
\text { issues which need } \\
\text { changing }\end{array}$ \\
\hline $\begin{array}{l}\text { 25-36 A more positive } \\
\text { perception }\end{array}$ & $\begin{array}{l}|5-2| \text { Not } \\
\text { too bad }\end{array}$ & $\begin{array}{l}25-36 \text { A more } \\
\text { positive atmosphere }\end{array}$ \\
\hline $\begin{array}{l}37-48 \text { Teaching highly } \\
\text { thought of }\end{array}$ & $\begin{array}{l}22-28 \text { Very } \\
\text { good socially }\end{array}$ & $\begin{array}{l}37-48 \text { A good feeling } \\
\text { overall }\end{array}$ \\
\hline
\end{tabular}

Abbreviation: DREEM, Dundee Ready Education Environment Measure. 
academic self-perception (eight items/max score 32), perception of atmosphere (12 items/max score 48), and social selfperception (seven items/max score 28 ). ${ }^{7}$ Data analysis was performed using SPSS software (v17; SPSS Inc., Chicago, IL, USA). The continuous variables were summarized as mean and standard deviation (SD) and utilized single-sample $t$-tests and one-way analysis of variance (ANOVA); post hoc multiple comparison by Tukey's method was also utilized. In this study, $P \leq 0.05$ was considered significant.

\section{Results}

A set of 493 usable responses (493/527, 93.54\%) was obtained, comprising 201 male (42\%) and 292 female (58\%) students. Their ages ranged from 17.8 to 29.5 years, with a mean age of $22 \pm 4$ years. Thirty-five point five percent (175) of students were in first year, 23.5\% (116) in second year, $24.5 \%$ (121) in third year, and $16.5 \%$ (81) in their fourth year of education.

The highest response rates were in midwifery (94.11\%), nursing (93.5\%), anesthesia (92.77\%), and radiology $(92.72 \%)$. The lowest response rate was in laboratory sciences students $(91.66 \%)$. Response rates in operating room nursing and medical emergency students were $91.66 \%$ and $92.1 \%$, respectively.

The overall mean score was 113.5 (SD 21.9) out of a maximum of 200 , corresponding to $56.74 \%$ of the maximum score (95\% confidence interval [CI]: 110-118). There were no statistically significant differences between the five domains. The grouped mean students' perception of learning was 27.4/48 (SD 5.7), which generated the highest individual domain score ( $57.2 \%$ of the maximum score). The pooled mean of students' perception of teachers was 24.6/44 (SD $3.9)$ (55.9\% of the maximum score), students' perception of atmosphere was 26.8 (SD 5.1), and academic self-perception was 20.5/38 (SD 6.3) produced the lowest individual domain scores $(55.8 \%$ and $53.94 \%$ of the maximum score). The grouped mean students' social self-perception was (15.7; SD 3.3; 56\%).

The mean total DREEM scores for operation room nursing students (121.8 \pm 21.7$)$, anesthesia students (120.5 \pm 14.3 ),

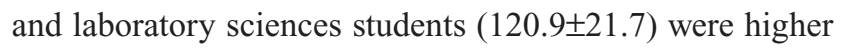
than for the other courses and the difference was significant $(P=0.001)$ as depicted in Figure 1. Students' perceptions of five DREEM domains except for the perception of teachers domain were statistically significantly different between the seven major courses $(P<0.01)$. Higher mean scores were found in students' perceptions of learning and teacher domains for operation room nursing students

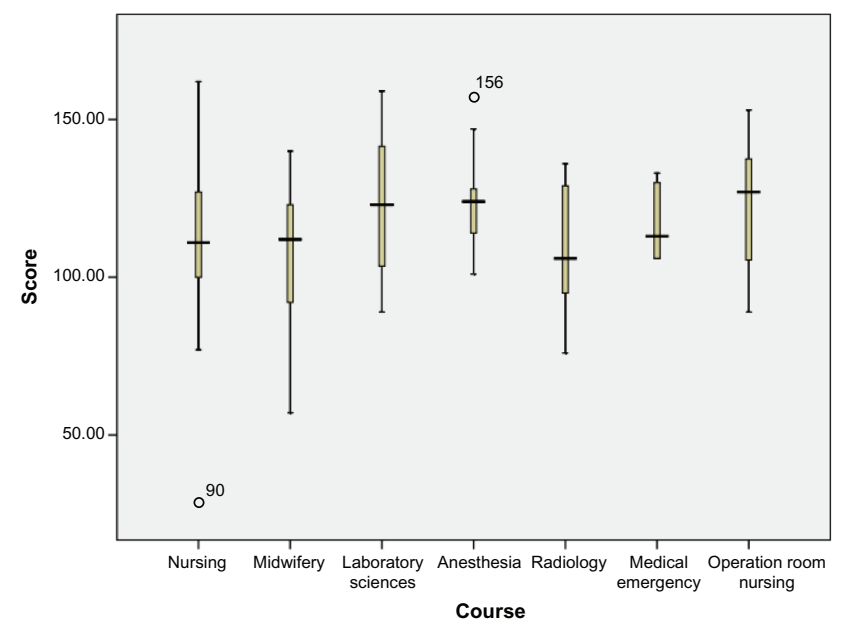

Figure I DREEM score by course name.

Abbreviations: DREEM, Dundee Ready Education Environment Measure.

(29.6 and 29.8, respectively); midwifery and radiology students had lower mean scores.

Moreover, the highest mean scores in the academic selfperception domain were in medical emergency (22.7) and laboratory sciences students (22.2). Higher mean scores were observed in the perception of students toward atmosphere in operation room nursing (29.5) and anesthesia students (28.9) and in the social self-perception domain, medical emergency (16.6) and anesthesia (16.3) students had the highest scores, while nursing and laboratory students had lower scores (Table 2).

Total DREEM scores were higher for females; this showed that there were statistically significant differences between the perceptions of the males and females $(P=0.03$; Table 3).

The data analyses showed that there was no statistically significant difference between the mean scores of the education climate and domains between single and married or native and non-native students $(P>0.05)$; however, there were statistically significant differences between the mean scores of whole DREEM domains - for the perceptions of learning, perceptions of teacher, perceptions of atmosphere in first, second, third, and fourth year students $(P=0.03)$. The scores for first and fourth year students were significantly higher than for the other students (Table 4).

Table 5 shows the DREEM scores per item. Eleven items had mean scores of $<2$, the maximum mean score was 3.10 ("I am encouraged to participate in class") and the lowest mean score was 1.5 ("there is a good support system for students who get stressed"). A total of 37 items (74\%) had aspects of the learning environment/climate that could be enhanced. 
Table 2 Mean (SD) subscale and total DREEM scores for Rafsanjan University of Medical Sciences disciplines (N=493)

\begin{tabular}{|c|c|c|c|c|c|c|c|}
\hline $\begin{array}{l}\text { Health science } \\
\text { discipline }\end{array}$ & $\begin{array}{l}\text { SPL } \\
(\max =48)\end{array}$ & $\begin{array}{l}\text { SPT } \\
(\max =44)\end{array}$ & $\begin{array}{l}\text { SAP } \\
(\max =38)\end{array}$ & $\begin{array}{l}\text { SPA } \\
(\max =48)\end{array}$ & $\begin{array}{l}\text { SSP } \\
(\max =28)\end{array}$ & $\begin{array}{l}\text { Overall } \\
\text { DREEM }\end{array}$ & $\begin{array}{l}\text { DREEM } \\
\text { (\%) }\end{array}$ \\
\hline Nursing & 27.4 & 24.3 & 20.3 & 26.8 & 15.6 & 114.3 & 57.15 \\
\hline$n=202$ & (5.9) & (5.9) & $(4.5)$ & $(5.6)$ & $(4.2)$ & $(20.6)$ & \\
\hline Midwifery & 24.8 & 23.5 & 18.3 & 25.4 & 15.2 & 106.23 & 53.1 \\
\hline$n=64$ & $(4.2)$ & $(4.2)$ & $(5.1)$ & (6.6) & $(4.7)$ & $(22.7)$ & \\
\hline Laboratory sciences & 28.6 & 25.5 & 22.2 & 28.2 & 14.1 & 120.95 & 60.2 \\
\hline $\mathrm{n}=44$ & $(5.8)$ & (8.4) & (6.5) & (5.6) & (4.8) & (21.7) & \\
\hline Anesthesia & 27.8 & 24.4 & 21.7 & 28.9 & 16.3 & 120.58 & 60.3 \\
\hline$n=51$ & (3.3) & (3.4) & $(5.2)$ & $(3.1)$ & $(10.8)$ & $(14.3)$ & \\
\hline Radiology & 24.9 & 23.2 & 18.5 & 24.1 & 14.7 & 105.6 & 52.3 \\
\hline$n=51$ & $(5.1)$ & (8.7) & (3.3) & (5.6) & (3.3) & $(19.5)$ & \\
\hline Operation room nursing & 29.6 & 29.8 & 21.3 & 29.5 & 14.5 & 121.87 & 60.9 \\
\hline$n=46$ & (7.9) & (3.7) & (3.5) & $(I I .2)$ & $(4.3)$ & $(21.7)$ & \\
\hline Medical emergency & 28.8 & 23.9 & 22.7 & 25.8 & 16.6 & 117.8 & 58.9 \\
\hline $\mathrm{n}=35$ & $(4.6)$ & $(4.1)$ & $(2)$ & (3) & $(2.1)$ & $(\mathrm{II} .7)$ & \\
\hline$P$-value & 0.03 & 0.4 & 0.001 & 0.001 & 0.001 & 0.001 & 0.001 \\
\hline Lower $95 \% \mathrm{Cl}$ & 26.15 & 23.5 & 19.5 & 26.12 & 14.67 & 110.62 & 55.67 \\
\hline Upper $95 \% \mathrm{Cl}$ & 27.3 & 24.6 & 20.4 & 27.28 & $|5.5|$ & II4.7I & 57.03 \\
\hline Total & 27.4 & 24.6 & 20.5 & 26.7 & 15.7 & 113.5 & 56.7 \\
\hline$N=493$ & $(5.7)$ & (3.9) & $(4.1)$ & $(5.1)$ & (3.3) & $(17.3)$ & \\
\hline Percentage for each domain & 57.2 & 55.9 & 53.9 & 55.8 & 56.0 & 56.7 & \\
\hline
\end{tabular}

Abbreviations: $\mathrm{Cl}$, confidence interval; DREEM, Dundee Ready Education Environment Measure; SAP, students' academic self-perception; SD, standard deviation; SPA, students' perception of atmosphere; SPL, students' perceptions of learning; SPT, students' perceptions of teaching; SSP, students' social self-perception.

The lowest scores (mean $\leq 2)$ were related to accommodation, teaching and teachers, and supporting systems (Table 5).

\section{Discussion}

Evaluation of the educational environment is an important element of program appraisal. ${ }^{15,42}$ We have used DREEM to estimate the perceptions of midwifery, nursing, radiology, operation room nursing, laboratory sciences, medical emergency, and anesthesia students of RUMS toward their educational environment. The students were interested in completing the DREEM questionnaire as evidenced by the good response rate.

Table 3 Mean (\%) subscale and total DREEM scores for Rafsanjan University of Medical Sciences students by sex $(\mathrm{N}=493)$

\begin{tabular}{lllll}
\hline Subscale & Female & Male & Total & $P$-value \\
\hline Perception of learning (\%) & 27.38 & 27.58 & 27.4 & 0.8 \\
(max =48) & $(57.05)$ & $(57.47)$ & $(57.2)$ & \\
Perceptions of teachers (\%) & 24.62 & 24.56 & 24.6 & 0.9 \\
$(\max =44)$ & $(55.96)$ & $(55.83)$ & $(55.9)$ & \\
Academic self-perception (\%) & 20.7 & 20.13 & 20.5 & 0.3 \\
$(\max =38)$ & $(64.73)$ & $(62.92)$ & $(64.11)$ & \\
Perceptions of atmosphere (\%) & 6.9 & 26.68 & 26.8 & 0.7 \\
$(\max =48)$ & $(56.04)$ & $(55.59)$ & $(55.89)$ & \\
Social self-perception (\%) & 16.16 & 15.03 & 15.7 & 0.09 \\
(max =28) & $(57.74)$ & $(53.71)$ & $(56.38)$ & \\
Total DREEM (\%) & 116.2 & 110.72 & 113.5 & 0.03 \\
& $(58.1)$ & $(55.36)$ & $(56.74)$ & \\
\hline
\end{tabular}

Abbreviation: DREEM, Dundee Ready Education Environment Measure; max, maximum.
The overall mean DREEM score for our subjects was found to be $113.5 / 200$ (56.9\%; 95\% CI: 55.67\%-57.03\%); this mean was well within the range (101-150) that is supposed to indicate a "more positive than negative" perception of environment. ${ }^{43}$ The operation room nursing, anesthesia, and laboratory sciences students had higher mean scores than for the other courses. DREEM overall scores for a Chinese nursing school ${ }^{40}$ and medical schools in Sri Lanka, Nepal, Nigeria, Saudi Arabia, the UK (Birmingham), Chile, Kuwait, Sweden, Jamaica, Trinidad, Dental School of Malaysia and International Medical University (Malaysia), ${ }^{44}$ University of British Columbia Medical School, ${ }^{4}$ India ${ }^{45}$ and Australia, ${ }^{26}$ the International University of Management (Bachelor of Nursing), ${ }^{46}$ Indonesian nursing students, ${ }^{47}$ and similar studies ${ }^{20,31,32,43,48-51}$ were in the same range (score 101-150), and based on the DREEM interpreting guide (Table 1), are considered to be more positive than negative.

There are also a few studies that have confirmed higher overall mean DREEM scores. A Malaysian private nursing college $^{52}$ and a nursing school in China reported high mean DREEM scores of 134.42 and 131.26 , respectively. ${ }^{53} \mathrm{~A}$ series of UK learning environment studies recorded a high mean DREEM score of $142.91 .{ }^{35}$ Reasonably high mean DREEM scores were found in a study in the UK at different teaching hospital centers $(139.20)^{42}$ and in seven major medical sciences courses at Monash University in Australia (137.3; $68.7 \%){ }^{26}$ The results of these studies suggest that the nursing, 
Table 4 Mean (SD) subscale and total DREEM scores for Rafsanjan University Medical Sciences students by year of enrollment ( $N=493$ )

\begin{tabular}{lllllll}
\hline Subscale & I st year & 2nd year & 3rd year & 4th year & Total DREEM & P-value \\
\hline Perception of learning $(\max =48)$ & $28.39(59.15)$ & $27.06(56.39)$ & $26.16(54.3)$ & $28.97(60.35)$ & $27.4(57.24)$ & 0.04 \\
Perception of teachers $(\max =44)$ & $26.49(60.2)$ & $23.23(52.8)$ & $23.21(52.76)$ & $25.38(57.7)$ & $24.60(55.91)$ & 0.001 \\
Academic self-perception $(\max =38)$ & $20.88(65.25)$ & $20.8(65.01)$ & $19.8(61.89)$ & $20.63(64.49)$ & $20.5(64.11)$ & 0.48 \\
Perceptions of atmosphere $(\max =48)$ & $28.29(58.94)$ & $25.69(53.53)$ & $25.9(53.97)$ & $27.19(56.65)$ & $26.8(55.89)$ & 0.008 \\
Social self-perception $(\max =28)$ & $15.66(55.95)$ & $15.68(56)$ & $16.19(57.83)$ & $15.3(54.66)$ & $15.7(56.07)$ & 0.8 \\
Total DREEM & $119.73(56.86)$ & $112.49(56.24)$ & $111.19(55.59)$ & $117.5(58.75)$ & $113.5(56.74)$ & 0.03 \\
\hline
\end{tabular}

Abbreviations: DREEM, Dundee Ready Education Environment Measure; SD, standard deviation.

midwifery, and paramedical schools of RUMS have achieved a more positive than negative status, which is just a level below the highest category of achievable scores. Students of innovative curricula have a tendency to show more satisfaction with their educational environments compared to students of traditional curricula. Higher DREEM scores tend to indicate more student-centered curricula, while those offering conventional curricula commonly score less than 120 out of $200 .^{11,15,31}$

The score descriptors ${ }^{2}$ that determine the level of improvement descriptors for the subscale scores of the actual DREEM indicate that students' perceptions of learning were positive and that their perceptions of the teachers were moving in the right direction. Their academic self-perception was found to be more positive, their perception of the atmosphere was that "a more positive atmosphere", and the students' social selfperception was "not too bad". Our sample's mean perceptions expressed as a percentage were between $53.447 \%-56.875 \%$ over five domains. These mean scores indicate that there was room for improvement in the aspects being measured by the DREEM in their school. This is similar to those in the validated DREEM study. ${ }^{54}$ The students perception can be used to initiate change and improvement. Medical education is very expensive and academic failure is wasteful both to society and to the individual. Consequently, we need to ensure that the environment is as conducive as possible to learning, thus reducing the risk of academic underachievement.

There was a statistically significant difference between sexes in the overall DREEM score, and in terms of the individual subscales, learning, academic, and social perceptions were the areas that showed the greatest difference between sexes, which is similar to the results from studies conducted in Australia, ${ }^{26}$ Sweden, ${ }^{55}$ Nigeria, ${ }^{39}$ and Dundee Medical School, where female students' perceptions were more positive. ${ }^{31}$ Conversely, our results are statistically significantly different to those of studies carried out in the Middle East, ${ }^{23,56}$ Trinidad, ${ }^{51}$ Sri Lanka,${ }^{50}$ and in India, ${ }^{45}$ which reported no significant sex differences between females and males. ${ }^{54}$ This suggests that the female students perceived factors such as curriculum, structure, focus, and goals more positively than their male counterparts and that the female students appeared to be happier than the males. It is not clear the extent to which this trend, and indeed, the trend that females perceived their course environments more favorably overall, can be generalized to other institutions. On the one hand, there is long standing evidence that males and females typically exhibit different learning styles, ${ }^{57}$ which could partly explain differences in the way they learn, and the environments generally, are perceived in the present study or can probably be accounted for by the different types of curricula. ${ }^{58}$ Perceptions of learning, the teacher, and atmosphere varied according to the students' year-level of enrollment. In the present study, students in first year had the highest score, with a mean of $119.73 \pm 56.86$. The second, third, and fourth year students' overall mean DREEM scores were in the range of 111.19-117.58; these findings are in line with those in a study by Mohd Said et al, ${ }^{46}$ who noted a trend for reduced scores in the senior years. It was suggested that this trend could be due to the fact that students genuinely believed that the learning environment was deteriorating, and thus were mentally tired of being a student and looking forward to leaving student life. The students' perceptions in first year could have been high initially, and dissatisfaction may have crept in as the novelty of joining a health science student body wore off unlike in other studies; ${ }^{26,32}$ this difference does not follow a consistent pattern year to year. Further investigation of each course separately, and perhaps individual items, is required to help clarify these differences.

Finally, it is worth mentioning that increased stress and tiredness, lack of a good stress support system, accommodation, and factual learning were also identified as the most significant problems by students. These problems are similar to those in some other universities. ${ }^{21,54}$ There have been very few Iranian studies on students' perceptions of the medical sciences college environment to date. ${ }^{13,38,41}$ The impression that teachers are knowledgeable and well-prepared for their classes but are too authoritarian and strict has also been stated by other studies. ${ }^{4,13,38,46,59}$ Assessments, which are an integral part 
Table 5 Mean (SD) scores for each DREEM item

Items

Mean (SD)

Factor I: students' perceptions of learning

40. The teachers are well-prepared for their classes

$2.44(1.27)$

2. The teachers are knowledgeable

$2.57(88)$

$2.18(952)$

$2.09(1.03)$

$2.18(1.08)$

23. The atmosphere is relaxed during lectures

24. The teaching time is put to good use

29. The teachers are good at providing feedback to students

45. Much of what I have to learn seems relevant

to a career in health care

37. The teachers give clear examples

12. The school is well-timetabled

7. The teaching is often stimulating

II. The atmosphere is relaxed during the ward teaching

38. I am clear about the learning objectives of the course

43. The atmosphere motivated me as a learner

47. Long-term learning is emphasized over short-term learning

Factor II: students' perceptions of teachers

50. The students irritate the teachers

8. The teachers ridicule the student

9. The teachers are authoritarian

39. The teachers get angry in class

48. The teaching is too teacher-centered

35. I find the experience disappointing

25. The teaching over-emphasizes factual learning

Factor III: students' social self-perceptions

3. There is a good support system for students who get stressed

6. The teachers are patient with patients

I. I am encouraged to participate in class

15. I have good friends in this school

4. I am too tired to enjoy this course

19. My social life is good

14. I am rarely bored on this course

Factor IV: students' perceptions of atmosphere

30. There are opportunities for me to develop interpersonal skills

31. I have learned a lot about empathy in my profession

4I. My problem-solving skills are being well developed here

16. The teaching helps to develop my confidence

19. My social life is good

32. The teachers provide constructive criticism here

2I. I feel I am being well prepared for my profession

13. The teaching is student-centered

22. The teaching helps to develop my confidence

34. The atmosphere is relaxed during seminars/tutorials

18. The teachers have good communication skills with patients

49. I feel able to ask the questions I want

33. I feel comfortable in class socially

Factor V: students' academic self-perceptions

27. I am able to memorize all I need

5. Learning strategies which worked for me before continue to work for me now

36. I am able to concentrate well
$2.35(2.71)$

$2.63(1.03)$

$2.30(0.921)$

$1.97(1.04)$

$1.96(1.13)$

$2.54(0.95)$

$2.27(1.01)$

2.69 ( 1.68$)$

$2.24(1.10)$

$1.78(1.08)$

$2.19(2.45)$

$1.73(0.99)$

$2.38(0.92)$

$2.04(1.12)$

$1.55(0.96)$

$2.24(1.10)$

1.75 (1.02)

$1.53(3.13)$

I.8I (0.88)

$3.10(2.31)$

$3(0.97)$

$2.43(1.10)$

$2.10(2.5 \mathrm{I})$

$1.96(1.13)$

$2.65(2.78)$

$2.64(1.61)$

$2.42(2.17)$

$2.80(0.97)$

$2.81(1.01)$

$2.03(0.93)$

$2.43(1.10)$

I.75 (I)

$2.78(0.94)$

$2.37(0.92)$

$2.26(0.82)$

2.21 (1.20)

$2.45(0.95)$

$2.17(1.05)$

2.31 (0.83)

2.02 (1.01)

(Continued)
Table 5 (Continued)

\begin{tabular}{ll}
\hline Items & Mean (SD) \\
\hline $\begin{array}{ll}\text { 26. Last year's work has been a good preparation for } \\
\text { this year's work }\end{array}$ & $2.49(0.95)$ \\
28. I seldom feel lonely & $2(I . I I)$ \\
42. The enjoyment outweighs the stress of studying & $2.23(1.20)$ \\
$\quad$ medicine & \\
44. The teaching encourages me to be an active learner & $2.54(0.94)$ \\
46. My accommodation is pleasant & $1.89(1.27)$ \\
I0. I am confident about passing this year & $2.78(2.02)$ \\
I7. Cheating is a problem in this school & $1.86(I .27)$ \\
Total mean DREEM & $113.5(I 7.3)$ \\
\hline
\end{tabular}

Abbreviations: DREEM, Dundee Ready Education Environment Measure; $\mathrm{SD}$, standard deviation.

of the educational process, need to be carefully planned and executed. They need to have clear objectives with provision for feedback so that remediation is available to those students who underperform and require additional support and monitoring. The experience of stress symptoms, eg, hostility, depression, and other debilitating effects, has been documented. The college environment is not the only source of stress; which is also influenced by the students' personality type, sex, sociocultural differences, and emotional intelligence, etc. A formal or informal support system could be developed so as to make the students more "positive" and more in "control of their education", which would help alleviate their stress ${ }^{59}$ and make the learning experience more enriching and fulfilling. ${ }^{60}$

While this study provides a valuable insight into the course environment as perceived by RUMS undergraduate students, it would be valuable to conduct a similar study at another Iranian university as well as at international institutions. Other limitations should also be acknowledged. Firstly, individual items were not analyzed, and qualitative data were not collected in order to more deeply address specific problems or highlight strengths within the university or particular courses.

\section{Conclusion}

This study suggests that students enrolled in the medical sciences courses at RUMS generally hold positive perceptions toward their course environment. Superior perceptions held by females and variations between year levels are consistent with results from other research. These, as well as differences between courses and study pathways, should be further investigated by analysis of specific items and subcohorts.

The DREEM gives a clear indication of the priorities for reform of the curriculum. These results can also serve as a baseline for a longitudinal quality assessment of students' perceptions for the colleges of RUMS, and it is necessary for improving the educational environment quality and 
effectiveness of an educational program in students learning, it enhances the ability for learning and makes a significant interest to student learning, motivation and learning outcomes, academic progress, and sense of well-being.

\section{Disclosure}

The authors report no conflicts of interest in this work.

\section{References}

1. Al Rukban MO, Khalil MS, Al-Zalabani A. Learning environment in medical schools adopting different educational strategies. Educ Res Rev. 2010;5(3):126-129.

2. Higgins S, Hall E, Wall K, Woolner P, McCaughey C. The impact of school environments: a literature review. The Centre for Learning and Teaching, School of Education, Communication and Language Science, University of Newcastle. Available from: http://www.ncl.ac.uk/cflat/ news/DCReport.pdf. Accessed September 11, 2014.

3. Arzuman H, Yusoff MS, Chit SP. Big Sib students' perceptions of the educational environment at the School of Medical Sciences, Universiti Sains Malaysia, using Dundee Ready Educational Environment Measure (DREEM) inventory. Malays J Med Sci. 2010;17(3):40-47.

4. Veerapen K, McAleer S. Students' perception of the learning environment in a distributed medical programme. Med Educ Online. 2010;15:5168.

5. Al-Ayed IH, Sheik SA. Assessment of the educational environment at the College of Medicine of King Saud University, Riyadh. East Mediterr Health J. 2008;14(4):953-959.

6. Lizzio A, Wilson K, Simons R. University students' perceptions of the learning environment and academic outcomes: implications for theory and practice. Studies in Higher Education. 2002;27(1):27-52.

7. Demirören M, Palaoglu Ö, Kemahli S, Özyurda F, Ayhan IH. Perceptions of students in different phases of medical education of educational environment: Ankara University Faculty of Medicine. Med Educ Online. 2008;13:8.

8. Edutech Wiki [webpage on the Internet]. Learning environment. Available from: http://edutechwiki.unige.ch/en/Learning_environment. Accessed September 11, 2014.

9. International standards in medical education: assessment and accreditation of medical schools' - educational programmes. A WFME position paper. The Executive Council, The World Federation for Medical Education. Med Educ. 1998;32(5):549-558.

10. Genn JM. AMEE Medical Education Guide No. 23 (Part 2): Curriculum, environment, climate, quality and change in medical education a unifying perspective. Med Teach. 2001;23(5):445-454.

11. Roff S, McAleer S. What is educational climate? Med Teach. 2001;23(4):333-334.

12. Harden RM. The learning environment and the curriculum. Med Teach. 2001;23(4):335-336.

13. Aghamolaei T, Fazel I. Medical students' perceptions of the educational environment at an Iranian Medical Sciences University. BMC Med Educ. 2010;10:87.

14. Al-Hazimi A, Zaini R, Al-Hyiani A, et al. Educational environment in traditional and innovative medical schools: a study in four undergraduate medical schools. Educ Health (Abingdon). 2004;17(2):192-203.

15. Roff S. The Dundee Ready Education Environment Measure (DREEM) a generic instrument for measuring students' perceptions of undergraduate health professions curricula. Med Teach. 2005;27(4):322-325.

16. Hong KS, Lai KW, Holton D. Students' satisfaction and perceived learning with a web-based course. Educ Technol Soc. 2003;6(1).

17. Rothman AI, Ayoade F. The development of a learning environment: a questionnaire for use in curriculum evaluation. J Med Educ. 1970;45(10):754-759.

18. Marshall RE. Measuring the medical school learning environment. J Med Educ. 1978;53(2):98-104.
19. Feletti GI, Clarke RM. Review of psychometric features of the Medical School Learning Environment Survey. Med Educ. 1981;15(2): 92-96.

20. Riquelme A, Oporto M, Oporto J, et al. Measuring students' perceptions of the educational climate of the new curriculum at the Pontificia Universidad Católica de Chile: performance of the Spanish translation of the Dundee Ready Education Environment Measure (DREEM). Educ Health (Abingdon). 2009;22(1):112.

21. Dimoliatis ID. [The Dundee Ready Education Environment Measure (DREEM) in Greek: how it should be used and preliminary experience in Greek medical educational environment]. Arch Hell Med. 2010:27(3):509-521. Greek.

22. Kumar Rana R, Kumar S, Kumar A, Roy V, Roy C. Analyzing the Dreams Coming True for Young Undergraduates of DMCH, Laherisarai, Darbhanga using DREEM Score. International Journal of Recent Trends in Science and Technology 2013;6(2):60-63.

23. Bouhaimed M, Thalib L, Doi SA. Perception of the educational environment by medical students undergoing a curricular transition in Kuwait. Med Princ Pract. 2009;18(3):204-208.

24. Whittle S, Whelan B, Murdoch-Eaton DG. DREEM and beyond; studies of the educational environment as a means for its enhancement. Educ Health (Abingdon). 2007;20(1):7.

25. Hutchinson L. Educational environment. BMJ. 2003;326(7393): 810-812.

26. Brown T, Williams B, Lynch M. The Australian DREEM: evaluating student perceptions of academic learning environments within eight health science courses. Int J Med Educ. 2011;2:94-101.

27. Khan JS, Tabasum S, Yousafzai UK. Determination of medical education environment in Punjab private and public medical colleges affiliated with University of Health Sciences, Lahore-Pakistan. J Ayub Med Coll Abbottabad. 2009;21(4):162-170.

28. Davenport ES, Sindi AM. Dental students perception of their educational environment. Available from: https://iadr.confex.com/ iadr/2008Toronto/techprogram/abstract_106929.htm. Accessed September 11, 2014.

29. Thomas BS, Abraham RR, Alexander M, Ramnarayan K. Students' perceptions regarding educational environment in an Indian dental school. Med Teach. 2009;31(5):e185-e186.

30. Zawawi AH, Elzubeir M. Using DREEM to compare graduating students' perceptions of learning environments at medical schools adopting contrasting educational strategies. Med Teach. 2012;34 Supp1 1: S25-S31.

31. Hammond SM, O’Rourke M, Kelly M, Bennett D, O'Flynn S. A psychometric appraisal of the DREEM. BMC Med Educ. 2012;12:2.

32. Till H. Climate studies: can students' perceptions of the ideal educational environment be of use for institutional planning and resource utilization? Med Teach. 2005;27(4):332-337.

33. Shehnaz SI, Sreedharan J, Gomathi KG. Faculty and students' perceptions of student experiences in a medical school undergoing curricular transition in the United Arab Emirates. Sultan Qaboos Univ Med J. 2012;12(1):77-85.

34. Tokuda Y, Goto E, Otaki J, et al. Undergraduate educational environment, perceived preparedness for postgraduate clinical training, and pass rate on the National Medical Licensure Examination in Japan. BMC Med Educ. 2010;10:35.

35. Edgren G, Haffling AC, Jakobsson U, McAleer S, Danielsen N. Comparing the educational environment (as measured by DREEM) at two different stages of curriculum reform. Med Teach. 2010;32(6):e233-e238.

36. Miles S, Leinster SJ. Medical students' perceptions of their educational environment: expected versus actual perceptions. Med Educ. 2007;41(3):265-272.

37. Carmody DF, Jacques A, Denz-Penhey H, Puddey I, Newnham JP. Perceptions by medical students of their educational environment for obstetrics and gynaecology in metropolitan and rural teaching sites. Med Teach. 2009;31(12):e596-e602.

38. Hamid B, Faroukh A, Mohammadhosein B. Nursing students' perceptions of their educational environment based on DREEM model in an Iranian University. Malays J Med Sci. 2013;20(4):56-63. 
39. Roff S, McAleer S, Ifere OS, Bhattacharya S. A global diagnostic tool for measuring educational environment: comparing Nigeria and Nepal. Med Teach. 2001;23(4):378-382.

40. McAleer S, Roff S. A practical guide to using the Dundee Ready Education Environment Measure (DREEM). In: Genn JM, editor. Curriculum, Environment, Climate, Quality and Change in Medical Education: a Unifying Perspective. AMEE Education Guide No 23. Dundee, UK: Association for Medical Education in Europe; 2001:29-33.

41. Soltani Arabshahi K, Koohpayehzadeh J, Khamseh ME. Investigation of Educational Climate in Major Clinical Wards in Iran University of Medical Sciences (IUMS) Based on DREEM Model. J Med Educ. 2008;12(1-2):10-15

42. Varma R, Tiyagi E, Gupta JK. Determining the quality of educational climate across multiple undergraduate teaching sites using the DREEM Inventory. BMC Med Educ. 2005;5(1):8

43. Zamzuri AT, Ali AN, Roff S, McAleer S. Students' perceptions of the educational environment at dental training college, Malaysia. Malays Dent J. 2004;25:15-26.

44. Lai N, Nalliah S, Jutti RC, Hla Y, Lim VK. The educational environment and self-perceived clinical competence of senior medical students in a Malaysian medical school. Educ Health (Abingdon). 2009;22(2):148.

45. Abraham R, Ramnarayan K, Vinod P, Torke S. Students' perceptions of learning environment in an Indian medical school. BMC Med Educ. 2008;8:20

46. Mohd Said N, Rogayah J, Hafizah A. A study of learning environments in the Kulliyyah (faculty) of Nursing, International Islamic University Malaysia. Malays J Med Sci. 2009;16(4):15-24.

47. Rahayo G R. Educational Climate at Nursing Study Program Gadjah Mada University as Measured Using DREEM. Artikel. Jurnal Pendidikan Kedokteran dan Profesi Kesehatan Indonesia. 2006;1(1):23.

48. Kiran HS, Gowdappa BH. "DREEM" comes true - Students' perceptions of educational environment in an Indian medical school. J Postgrad Med. 2013;59(4):300-305.

49. Dunne F, McAleer S, Roff S. Assessment of the undergraduate medical education environment in a large UK medical school. Health Educ J. 2006;65(2):149-158.
50. Jiffry MT, McAleer S, Fernando S, Marasinghe RB. Using the DREEM questionnaire to gather baseline information on an evolving medical school in Sri Lanka. Med Teach. 2005;27(4):348-352.

51. Bassaw B, Roff S, McAleer S, et al. Students' perspectives on the educational environment, Faculty of Medical Sciences, Trinidad. Med Teach. 2003;25(5):522-526.

52. Intan ID. A study of stressor and coping strategies among first year nursing students in the college of Polytech Mara, Kota Bahru Kelantan [master's thesis]. Kubang Kerian: Universiti Sains Malaysia; 2007.

53. Xueqin G, Yan H, Zhen-juan Z. [Influence of education environment on humanistic caring ability of college nursing students]. J Nurs Sci. 2010;14. Chinese.

54. Kossioni AE, Varela R, Ekonomu I, Lyrakos G, Dimoliatis ID Students'perceptions of the educational environment in a Greek Dental School, as measured by DREEM. Eur J Dent Educ. 2012;16(1): e73-e78.

55. Jakobsson U, Danielsen N, Edgren G. Psychometric evaluation of the Dundee Ready Educational Environment Measure: Swedish version. Med Teach. 2011;33(5):e267-e274.

56. Al-Hazimi A, Al-Hyiani A, Roff S. Perception of the educational environment of the medical school in King Abdul Aziz University, Saudi Arabia. Med Teach. 2004;26(6):570-573.

57. Philbin M, Meier E, Huffman S, Boverie P. A survey of gender and learning styles. Sex Roles. 1995;32(7-8):485-494.

58. Avalos G, Freeman C, Dunne F. Determining the quality of the medical educational environment at an Irish medical school using the DREEM inventory. Ir Med J. 2007;100(7):522-525.

59. Abdulghani HM, AlKanhal AA, Mahmoud ES, Ponnamperuma GG, Alfaris EA. Stress and its effects on medical students: a cross sectional study at a college of medicine in Saudi Arabia. J Health Popul Nutr. 2011;29(5):516-522.

60. Tripathy S, Dudani S. Students' perception of the learning environment in a new medical college by means of the DREEM inventory. Int $J$ Res Med Sci. 2013;1(4):385-391.
Advances in Medical Education and Practice

\section{Publish your work in this journal}

Advances in Medical Education and Practice is an international, peerreviewed, open access journal that aims to present and publish research on Medical Education covering medical, dental, nursing and allied health care professional education. The journal covers undergraduate education, postgraduate training and continuing medical education

\section{Dovepress}

including emerging trends and innovative models linking education, research, and health care services. The manuscript management system is completely online and includes a very quick and fair peer-review system. Visit http://www.dovepress.com/testimonials.php to read real quotes from published authors. 